\title{
Effect of Salinity Stress on Capsicum annuum Callus Growth, Regeneration and Callus Content of Capsaicin, Phenylalanine, Proline and Ascorbic Acid
}

\author{
Zahra N. Al Hattab ${ }^{1}$, Saadon A. Al-Ajeel ${ }^{2}$ and Ekhlas A. El Kaaby ${ }^{1}$ \\ 1. Department of Genetic Engineering, Biotechnology Center, Ministry of Science and Technology, Baghdad 10001, Iraq \\ 2. Department of Biology, Faculty of Education, University of Kufa, An-Najaf 54001, Iraq
}

Received: July 20, 2015 / Accepted: July 26, 2015 / Published: July 30, 2015.

\begin{abstract}
The present research was conducted to study salinity effect on callus growth and regeneration from the local Chilli pepper cultivar as well as calli content of capsaicin, phenylalanine, proline and ascorbic acid. The results showed that the Pericarp gave the highest fresh and dry weight of $511.6 \mathrm{mg}$ and $56.95 \mathrm{mg}$ respectively at $9 \mathrm{dSm}^{-1}$ compared with other interactions. Moreover the lowest fresh and dry weight was recorded for the root calli grown at $12 \mathrm{dSm}^{-1}$. The highest regeneration percentage was $87.20 \%$ at 3 $\mathrm{dSm}^{-1}$ and the lowest was $6.70 \%$ at $9 \mathrm{dSm}^{-1}$. For explant effect on regeneration, the highest percentage was $71.1 \%$ for shoot tips and the lowest was $23.30 \%$ from the pericarp. However no plants were regenerated at $12 \mathrm{dSm}^{-1}$ from all explants and at $9 \mathrm{dSm}^{-1}$ from calli induced from roots, placenta and pericarps. Calli induced from Pericarp contain significantly higher Proline amount at $12 \mathrm{dSm}^{-1}$ which was $34.65 \mu \mathrm{g} / \mathrm{g}$ and the lowest was $2.57 \mu \mathrm{g} / \mathrm{g}$ at $3 \mathrm{dSm}^{-1}$. Moreover Phenylalanine ranged from $28.23 \mu \mathrm{g} / \mathrm{g}$ at $3 \mathrm{dSm}{ }^{-1}$ and $41.50 \mu \mathrm{g} / \mathrm{g}$ at $12 \mathrm{dSm}^{-1}$. While a wide range between the explants in the Ascorbic acid amount was recorded. The highest was 47.21 $\mu \mathrm{g} / \mathrm{g}$ from the Placenta calli and the lowest was $0.98 \mu \mathrm{g} / \mathrm{g}$ from the Shoot tip calli. On the other hand calli produced from Placenta gave the highest amount of Capsaicin $53.11 \mu \mathrm{g} / \mathrm{g}$ at $9 \mathrm{dSm}^{-1}$ which was not significantly different than the placenta and the pericarp at $12 \mathrm{dSm}^{-1}$ and the shoot tips, placenta and the pericarp at $9 \mu \mathrm{g} / \mathrm{g}$. In conclusion Chili pepper callus tolerated salinity via the accumulation of Ascorbic acid, Proline, Phenylalanine and Capsaicin. Moreover Chili Pepper grown In vitro under salt stress contained high amount of Capsaicin the important pharmaceutical compound. Finally pepper plants were regenerated from salt stressed calli might be salt tolerant under field conditions.
\end{abstract}

Key words: Chili pepper, In vitro proline, phenylalanine, ascorbic acid and capsaicin.

\section{Introduction}

Chili pepper is an important source for vitamin A, $\mathrm{C}$ and $\mathrm{E} 1$ as well as secondary products such as flavonoids, phenolic acids and carotenoids [1, 2]. Moreover, it contains capsaicin which gives the fruits a punchy test. This alkaloid has wide medicinal and pharmaceutical applications. It has been used as pane killer and to treat arthritis [3] and to reduce cholesterol. Capsaicin has also been used as fungicide [4].

Tissue culture technique provides suitable

Corresponding author: Zahra N. Al Hattab., Ph.D., research fields: plant biotechnology, genetic and breeding. E-mail: zahramost55@yahoo.com. environment for studying the secondary metabolites and the factors that affect their production with a systematic approach to improve their production [5]. Plant secondary metabolites production is influenced by biotic and abiotic stress signals [2]. Salinity is a major constrain which poison plant cells due to free radicals formation. To cope with the stress, plants developed several mechanisms including morphological and structural changes and increasing the secondary products [6]. Salt stress effect on plant cells metabolism and the production of carbohydrates, proteins [7, 8], and enzymes [9] have been investigated in vitro in some plants. The main 
objective of current research was to study the effect of salt stress on chili pepper callus growth and it's contained of capsaicin and some amino acids as well as plant regeneration from salt stressed calli.

\section{Materials and Methods}

The present research was conducted at The Ministry of Science and Technology/Directorate of Agricultural Research, Genetic Engineering Department during the years 2012-2014. Local chili pepper cultivar was used in the study.

The seeds and the fruits were surface sterilized for one min with $70 \%$ Ethanol. Then they were submerged in $4 \%$ sodium hypochlorite $(\mathrm{NaOCI}$ ) for 20 min with continuous stirring and washed with sterile distilled water trice $5 \mathrm{~min}$ each.

The seeds were grown on MS medium [10] supplemented with $2 \mathrm{mg} / \mathrm{L}$ Glycine, $2 \mathrm{mg} / \mathrm{L} \mathrm{GA}_{3}, 0.5$ $\mathrm{mg} / \mathrm{L}$ Nicotinic acid, $0.5 \mathrm{mg} / \mathrm{L}$ Pyridoxine, $0.1 \mathrm{mg} / \mathrm{L}$ Thiamine, $100 \mathrm{mg} / \mathrm{L}$ Inositol, $3000 \mathrm{mg} / \mathrm{L}$ Sucrose and $6000 \mathrm{mg} / \mathrm{L}$ Agar. Fourteen days old seedlings were used as explants source. Calli were induced from shoot tips $(1 \mathrm{~cm})$, cotyledon leaves, hypocotyls and roots by culturing them on the same medium with out $\mathrm{GA}_{3}$ and with the addition of $2 \mathrm{mg} / \mathrm{L}$ of Kint and IAA. While the placente and the pericarp were grown on the same medium but with addition of $2 \mathrm{mg} / \mathrm{L}$ 2,4-D.

Salt stress was achived by the addition of sodium chloride to MS medium to give electric conductivity of 6,9 and $12 \mathrm{dSm}^{-1}$ media. The control was $3 \mathrm{dSm}^{-1}$, which was achived by using half strength MS medium. Constan weight $(100 \mathrm{mg})$ of the induced calli from all the explants were cultured on the corisponding medium with ten replications for each salt level and after 6 weeks fresh and dry weights were masured.

Capsaicin was extracted from all calli and estimating according to the procedure of AlOthman et al. [11] with slight modifications. Amino acids were estimated using the method of Jones and Gilli [12] and Ascorbic acid was estimated according to Mitic et al. [13] with slight modifications calli from all stress media were transferred to horrmoe free MS medium for regeneration. All the experiments were conducted in C.R.D (Completely Randomized Design) and the results were analysed by GenStat soft ware program [14].

\section{Results}

\subsection{Sodium Chloride Effect on Callus Fresh and Dry Weights}

The results (Tables 1 and 2) showed significant increase in the fresh and dry weights of the calli as the salinity level increased and decreased at $12 \mathrm{dSm}^{-1}$. The highest fresh and the dry weights were $432.72 \mathrm{mg}$ and $34.96 \mathrm{mg}$ respectively at $9 \mathrm{dSm}^{-1}$ salinity level compared with $283.57 \mathrm{mg}$ and $25.44 \mathrm{mg}$ at $3 \mathrm{dSm}^{-1}$. Moreover the pericarp gave significantly higher calli fresh and dry weights than the other explants which were $398.59 \mathrm{mg}$ and $42.17 \mathrm{mg}$ respectively. However the roots gave the lowest calli fresh and dry weights of $275.38 \mathrm{mg}$ and $17.28 \mathrm{mg}$ respectively. Analysis of the interaction between the salt levels and the explants showed that the Pericarp gave the highest fresh and dry weights of $511.6 \mathrm{mg}$ and $56.95 \mathrm{mg}$ respectively at $9 \mathrm{dSm}^{-1}$ compared with other interactions. The lowest fresh and dry weights were for the root calli grown at $12 \mathrm{dSm}^{-1}$.

The results (Table 3) showed that the percentage of plant regeneration is decreased as the salinity level increased. The highest percentage was $87.20 \%$ at 3 $\mathrm{dSm}^{-1}$ and the lowest was $6.70 \%$ at $9 \mathrm{dSm}^{-1}$. For explant effect on regeneration, there was no significant difference between calli induced from shoot tips and Cotyledons but both were significantly higher than the other explants. The highest percentage of plant regeneration was $71.1 \%$ for shoot tips followed by $66 \%$ Cotyledons. The lowest percentage was $23.30 \%$ which was recorded from calli induced from the pericarp. The interaction analysis showed that at 3 $\mathrm{dSm}^{1} 100 \%$ regeneration was obtained from the calli induced from shoot tips, cotyledons, hypocotyls and roots. However no plants were regenerated at $9 \mathrm{dSm}^{-1}$ 
Table 1 Effect of salinity stress on callus fresh weight $(\mathrm{mg})$ from different chili pepper explants (100 mg initial weight) after 6 weeks.

\begin{tabular}{llllll}
\hline Explants & \multicolumn{5}{c}{ Salt levels dSm $^{-1}$} \\
\cline { 2 - 5 } & 3 & 6 & 9 & 12 & Mean \\
\hline Shoot tips & 269.95 & 377.42 & 415.61 & 328.46 & 347.86 \\
Cotyledon & 319.81 & 350.14 & 436.84 & 332.43 & 359.8 \\
Hypocotyls & 315.07 & 390.76 & 422.71 & 319.87 & 362.1 \\
Roots & 220.05 & 243.55 & 354.16 & 283.75 & 275.38 \\
Placenta & 286.44 & 436.11 & 455.42 & 321.03 & 374.75 \\
Pericarp & 290.08 & 456.99 & 511.60 & 335.68 & 398.59 \\
Mean & 283.57 & 375.83 & 432.72 & 320.20 & \\
\hline
\end{tabular}

L.S.D ${ }_{(0.05)}$ salt levels 14.45 interaction 22.46 explants 17.23.

Table 2 Effect of salinity stress on callus dry weight (mg) from different chili pepper explants (100 mg initial weight ) after 6 weeks.

\begin{tabular}{llllll}
\hline \multirow{2}{*}{ Explants } & \multicolumn{5}{c}{ Salt levels dSm $^{-1}$} \\
\cline { 2 - 6 } & 3 & 6 & 9 & 12 & Mean \\
\hline Shoot tips & 17.60 & 31.3 & 34.55 & 27.42 & 27.72 \\
Cotyledon & 21.51 & 28.99 & 31.83 & 25.63 & 26.99 \\
Hypocotyls & 23.14 & 36.64 & 36.25 & 22.51 & 17.63 \\
Roots & 17.98 & 23.49 & 14.12 & 13.54 & 34.88 \\
Placenta & 37.13 & 42.49 & 36.06 & 23.85 & 42.17 \\
Pericarp & 35.29 & 44.46 & 56.95 & 31.98 & 24.16 \\
Mean & 25.44 & 34.56 & 34.96 & & \\
\hline
\end{tabular}

L.S.D ${ }_{(0.05)}$ salt levels 3.64 interaction 8.91 explants 4.46.

Table 3 Plant regeneration \% from salt stressed callus induced from different chili pepper explants.

\begin{tabular}{lllll}
\hline \multirow{2}{*}{ Explants } & \multicolumn{3}{c}{ Salt levels dSm $\mathrm{dS}^{-1}$} & Mean \\
\cline { 2 - 5 } & 3 & 6 & 9 & 71.1 \\
Shoot tips & 100 & 90.0 & 23.3 & 66.0 \\
Cotyledon & 100 & 86.7 & 11.3 & 54.1 \\
Hypocotyls & 100 & 56.7 & 5.7 & 60.0 \\
Roots & 100 & 80.0 & 0 & 46.7 \\
Placenta & 66.7 & 73.3 & 0 & 23.3 \\
Pericarp & 56.7 & 13.3 & 0 & 6.70 \\
Mean & 87.2 & 66.7 & &
\end{tabular}

L.S.D $(0.05)$ salt levels 5.32 interaction 13.02 explants 7.52.

from calli induced from roots, placenta and pericarps. The results indicated that although fruit explants gave calli with higher fresh and dry weights than the other explants (Tables 1 and 2); they gave lower percentage of plant regeneration under the conditions of the current experiment. Moreover, despite that, calli color changed to dark brown under the effect of salinity but it did not lose its regeneration ability (Fig. 1) except at $12 \mathrm{dSm}^{-1}$ no plants were regenerated from all calli grown in this salinity level.

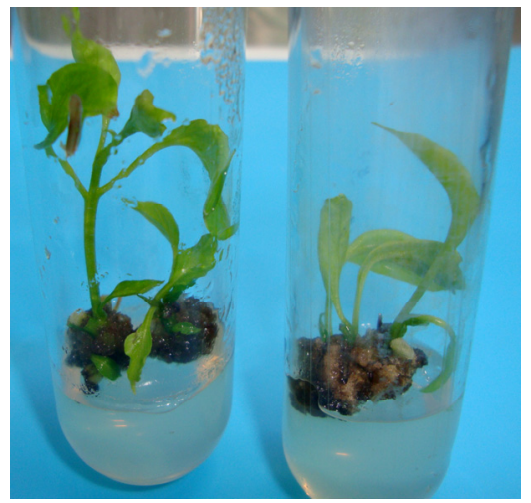

Fig. 1 Plant regeneration from stressed dark callus . 
The results (Table 4) showed that as salinity level increased the calli proline content increased. The highest amount was $18.62 \mu \mathrm{g} / \mathrm{g}$ at $12 \mathrm{dSm}^{-1}$ which was significantly higher than the other treatments. Calli induced from pericarp and placenta calli contain 16.35 and $16.12 \mu \mathrm{g} / \mathrm{g}$ proline respectively which were significantly higher than other explants. Interaction analysis showed that calli induced from pericarp contain significantly higher proline amount at 12 $\mathrm{dSm}^{-1}$ which was $34.65 \mu \mathrm{g} / \mathrm{g}$ and the lowest $2.57 \mu \mathrm{g} / \mathrm{g}$ at $3 \mathrm{dSm}^{-1}$ compared with the other treatments.

The results (Table 5) showed that calli induced from the placenta and the pericarp gave 43.23 and $40.34 \mu \mathrm{g} / \mathrm{g}$ phenylalanine respectively and both are significantly different than the other explants. Calli induced from the Shoot tips contained the lowest amount of phenylalanine $25.30 \mu \mathrm{g} / \mathrm{g}$. In addition as the salinity increased the amount of phenylalanine was increased as well. It was ranged from $28.23 \mu \mathrm{g} / \mathrm{g}$ at 3 $\mathrm{dSm}^{-1}$ and $41.50 \mu \mathrm{g} / \mathrm{g}$ at $12 \mathrm{dSm}^{-1}$. Calli induced from placenta and pericarp grown on media supplemented with 6 , 9, or $12 \mathrm{dSm}^{-1}$ contain significantly higher amount of phenylalanine compared with the other combinations except the root calli grown on $12 \mathrm{dSm}^{-1}$.

The results (Table 6) showed that salinity had adverse effect on calli content of ascorbic acid. The lowest amount was $11.51 \mu \mathrm{g} / \mathrm{g}$ at $3 \mathrm{dSm}^{-1}$ and increased to $20.10 \mu \mathrm{g} / \mathrm{g}$ at $6 \mathrm{dSm}^{-1}$ which was significantly different than the other salinity levels and reduced gradually to $17.58 \mu \mathrm{g} / \mathrm{g}$ at $12 \mathrm{dSm}^{-1}$. Wide range between the explants in the ascorbic acid amount was recorded. The highest was $(47.21 \mu \mathrm{g} / \mathrm{g})$ from the placenta calli and the lowest was $(0.98 \mu \mathrm{g} / \mathrm{g})$ from the shoot tip calli. The interaction analysis showed no constant relationship between the salinity level and the ascorbic acid amount among the explants. For the placenta and the pericarp the maximum amounts were $(62.91 \mu \mathrm{g} / \mathrm{g}$ and $48.62 \mu \mathrm{g} / \mathrm{g}$ respectively) at $6 \mathrm{dSm}^{-1}$ and reduced as the salinity level increased. While for the shoot tip, cotyledons and the hypocotyls the maximum amount was at 9 $\mathrm{dSm}^{-1}$. However for the roots, ascorbic acid amount continued to increase as the salinity level increased.

Table 4 Effect of salinity Stress on proline content $(\mu \mathrm{g} / \mathrm{g})$ of callus induced from different explants of chili pepper.

\begin{tabular}{llllll}
\hline \multirow{2}{*}{ Explants } & \multicolumn{5}{c}{ Salt levels dSm } \\
\cline { 2 - 6 } & 3 & 6 & 9 & 10.5 & 12 \\
\hline Shoot tips & 6.65 & 4.01 & 9.23 & 12.56 & 8.43 \\
Cotyledon & 6.24 & 3.14 & 13.98 & 14.76 & 8.34 \\
Hypocotyls & 7.34 & 5.56 & 7.18 & 12.03 & 9.73 \\
Roots & 6.03 & 6.79 & 22.62 & 14.07 & 8.52 \\
Placenta & 8.22 & 10.36 & 17.97 & 23.64 & 16.21 \\
Pericarp & 2.57 & 10.22 & 13.58 & 34.65 & 16.35 \\
Mean & 6.18 & 6.68 & & 18.62 & \\
\hline
\end{tabular}

L.S.D $(0.05)$ salt levels 3.22 interaction 9.05 explants 5.83.

Table 5 Effect of salinity stress on phenylalanine content $(\mu \mathrm{g} / \mathrm{g})$ of callus induced from different explants of chili pepper.

\begin{tabular}{llllll}
\hline Explants & \multicolumn{5}{c}{ Salt levels dSm } \\
\cline { 2 - 6 } & 3 & 6 & 9 & 12 & Mean \\
\hline Shoot tips & 18.09 & 16.15 & 33.16 & 33.78 & 25.30 \\
Cotyledons & 27.34 & 31.7 & 37.17 & 43.41 & 34.91 \\
Hypocotyls & 29.36 & 35.76 & 38.53 & 35.11 & 34.69 \\
Roots & 24.15 & 29.01 & 33.52 & 43.45 & 32.53 \\
Placenta & 38.14 & 40.48 & 46.23 & 48.06 & 43.23 \\
Pericarp & 32.27 & 39.88 & 43.98 & 45.21 & 40.34 \\
Mean & 28.23 & 32.16 & 38.77 & 41.50 & \\
\hline
\end{tabular}

L.S.D $(0.05)$ salt levels 2.07 interaction 9.03 explants 5.12. 
Table 6 Effect of salinity stress on Ascorbic acid content $(\mu \mathrm{g} / \mathrm{g})$ of callus induced from different explants of chili pepper.

\begin{tabular}{llllll}
\hline \multirow{2}{*}{ Explants } & \multicolumn{5}{c}{ Salt levels dSm ${ }^{-1}$} \\
\cline { 2 - 6 } & 3 & 6 & 9 & 12 & Mean \\
\hline Shoot tips & 0.98 & 1.25 & 1.36 & 0.33 & 0.98 \\
Cotyledon & 2.13 & 5.12 & 7.20 & 7.15 & 5.40 \\
Hypocotyls & 1.70 & 3.95 & 11.53 & 9.30 & 6.62 \\
Roots & 1.32 & 4.10 & 5.02 & 12.24 & 5.67 \\
Placenta & 34.79 & 62.91 & 46.83 & 44.29 & 47.21 \\
Pericarp & 28.16 & 48.62 & 43.35 & 32.17 & 38.08 \\
Mean & 11.51 & 20.10 & 19.22 & 17.58 & \\
\hline
\end{tabular}

L.S.D $(0.05)$ salt levels 0.95 interaction 6.13 explants 4.38 .

Table 7 Effect of salinity stress on Capsaicin content $(\mu \mathrm{g} / \mathrm{g})$ of callus induced from different explants of chili pepper.

\begin{tabular}{llllll}
\hline Explants & \multicolumn{5}{c}{ Salt levels dSm } \\
\cline { 2 - 6 } & 3 & 6 & 9 & 12 & Mean \\
\hline Shoot tips & 21.87 & 32.84 & 41.87 & 30.54 & 31.78 \\
Cotyledon & 16.08 & 17.22 & 29.67 & 33.26 & 24.06 \\
Hypocotyls & 11.43 & 14.1 & 26.35 & 22.56 & 18.61 \\
Roots & 6.09 & 6.48 & 18.78 & 10.32 & 10.42 \\
Placenta & 37.94 & 44.55 & 53.11 & 51.62 & 46.81 \\
Pericarp & 32.17 & 35.11 & 49.14 & 48.12 & 41.14 \\
Mean & 20.93 & 25.05 & 36.49 & 32.74 & \\
\hline
\end{tabular}

L.S.D $(0.05)$ salt levels 1.11 interaction 6.22 explants 4.07.

The results (Table 7) of capsaicin content analysis showed that as the salinity increased the capsaicin increased and the highest amount was $(36.49 \mu \mathrm{g} / \mathrm{g})$ recorded at $9 \mathrm{dSm}^{-1}$. However at $12 \mathrm{dSm}^{-1}$ Capsaicin reduced to $32.74 \mu \mathrm{g} / \mathrm{g}$. For explant effect calli induced from Placenta gave the highest amount $(46.81 \mu \mathrm{g} / \mathrm{g})$ compared with the other explants. Moreover the interaction analysis showed that calli produced from placenta gave the highest amount of capsaicin (53.11 $\mu \mathrm{g} / \mathrm{g}$ ) at $9 \mathrm{dSm}^{-1}$ which was not significantly different than the placenta and the pericarp at $12 \mathrm{dSm}^{-1}$ and the shoot tips, placenta and the pericarp at $9 \mu \mathrm{g} / \mathrm{g}$. The lowest amount $(6.09 \mu \mathrm{g} / \mathrm{g})$ was recorded from the root calli at $3 \mathrm{dSm}^{-1}$.

\section{Discussions}

Callus fresh and dry weights reduction at $3 \mathrm{dSm}^{-1}$ might be related to nutrients deficiency in this medium since it contained half the amount of salts. Full strength MS is required for plant cell division and growth. On the other hand the callus growth reduction at the highest salt level is due to the osmotic stress in this medium which inhibit mineral nutrients uptake and affect the ions availability to the cells [15]. In contrast other researchers found that high salinity level increase the plant growth hormones such as ABA and jasmonates which have an important role in salt tolerance [16] In addition the gradual increase in the fresh and dry weights from 6 to $9 \mathrm{dSm}^{-1}$ may be due to cell adaptation to the high salinity by the regulation of the osmotic pressure in the cells.

High salinity level prevented plant regeneration from calli produced from all the explants. Accumulation of $\mathrm{Na}^{+}$and $\mathrm{Cl}^{-}$ions in the cells inhibit the growth regulators syntheses which are required for cell differentiation. High ions concentration dehydrates and poisons the cells. Salinity results in the dehydration of the cells and reduces the availability of nutrients which is reflected in the inhibition of their growth [17]. No plants regenerated from placenta and pericarp calli, this might be because of the phenolic compounds produced by the fruit tissue. Several 
researchers reported high phenolic compounds in pepper fruits $[18,19]$.

When plants expose to salt stress it accumulate secondary products [20] and amino acids [21, 22]. Proline and phenylalanine are among the amino acids which are produced by some plants under salt stress. From the current experiment the proline amount increased as the salinity increased. Proline is accumulated in the cytoplasm to survive the osmotic stress caused by high salt concentration. Moreover it has been reported that proline provides osmoprotection $[23,24]$. The high amount of proline in the cell will increase the phenol compounds through the biosynthesis pathway of proline-linked pentose phosphate which will enhance shikimate and phenyl propanoid synthesis [25] which may suppress callus growth these results are disagree with Abbas et al. [26]. They found significant increment in callus fresh weight in the presence of proline in callus culture media.

On the other hand accumulation of Ascorbic acid in the cells is an adaptive mechanism to tolerate salinity stress [27]. Ascorbic acid is an antioxidant which alleviate the harmful effects of $\mathrm{NaCl}$ salinity [28, 29]. Transforming potato with GalUR gene which enhanced its ascorbic acid content, reduced the damage occurred by salt stress. Thus Upadhyaya et al. [30] concluded that engineering of ascorbate pathway enzymes is a major step in the development of salt tolerant crop plants. Pretreatment of lentil seeds with ascorbic acid reduced the effects of salt stress and improved its grain yield [31].

Accumulation of alkaloids in plants growing under biotic and abiotic stress has been reported by many researchers [8]. Particularly capsaicin production is increased in pepper grown under salt stress [32]. The same result was reported by Ali et al. [33] as salinity increased the capsaicin and vitamin $\mathrm{C}$ was increased.

In conclusion Chili pepper callus tolerated salinity via the accumulation of ascorbic acid, proline, phenylalanine and capsaicin. Moreover chili pepper grown in vitro under salt stress contained high amount of capsaicin the important pharmaceutical compound. Finally pepper plants regenerated from salt stressed calli might be salt tolerant under field conditions with high content of capsaicin.

\section{References}

[1] Medina-Juárez, L. Á., Molina-Quijada, D. M. A., Toro-Sánchez, G. C. L. D., González-Aguilar, G. A., and Gámez-Meza, N. 2012. "Antioxidant Activity of Peppers (Capsicum annuum L.) Extracts and Characterization of Their Phenolic Constituents." Interciencia 37 (8): 588-93.

[2] Mani, F. 2015. "Effect of Water Stress on Some Biochemical and Physiological Characters of Chili Pepper (Capsicum frutescens L.)." JECET 4 (1): 75-83.

[3] Arora, R., Gill, N. S., Chauhan, G., and Rana, A. C. 2011. "An Overview about Versatile Molecule Capsaicin." International Journal of Pharmaceutical Sciences and Drug Research 3 (4): 280-6.

[4] Soumya, S. L., and Nair, B. R. 2012. "Antifungal Efficacy of Capsicum frutescens L. Extracts Against Some Prevalent Fungal Strains Associated with Groundnut Storage." Journal of Agri. Tech. 8 (2): 739-50.

[5] Ahmed, S., Garg, M., Tamboli, E. T., Abdin, M. Z., and Ansari, S. H. 2013. "In vitro Production of Alkaloids: Factors, Approaches, Challenges and Prospects." Pharmacogn Rev. 7 (13): 27-33.

[6] Cecoli, G., Ramos, J. C., Ortega, L. I., Acosta, J. M., and Perreta, M. G. 2011. "Salinity Induced Anatomical and Morphological Changes in Chloris gayana Kunth Roots." Biocell 35 (1): 9-17.

[7] Mohamed, A. N., and Ismail, M. R. 2011. "Changes in Organic and Inorganic Solutes of in vitro Tomato Cultivars under NaCl Stress." AJCS 5 (8): 939-44.

[8] Šutković, J., Ler, D., and Gawwad, A. M. R. 2011. "In Vitro Production of Solasodine Alkaloid in Solanum Nigrum Under Salinity Stress." J. Phytol 3 (1): 43-9.

[9] Gao, S., Ouyang, C., Wang, S., Xu, Y., Tang, L., and Chen, F. 2008. "Effects of Salt Stress on Growth, Antioxidant Enzyme and Phenylalanine Ammonia-Lyase Activities in Jatropha curcas L. Seedlings." Plant Soil Environ 54 (9): 374-81.

[10] Murashige, T., and Skoog, F. 1962. "A Revised Medium for Rapid Growth and Bio Assays with Tobacco Tissue Cultures." Physiol. Pl. 15: 473-97.

[11] AlOthman, Z. A. A., Ahmed, Y. B. H., Habila, M. A., and Ghafar, A. A. 2011. "Determination of Capsaicin and Dihydrocapsaicin in Capsicum Fruit Samples Using High Performance Liquid Chromotography." Molicules 16: 8919-29. 

Capsaicin, Phenylalanine, Proline and Ascorbic Acid

[12] Jones, B. N., and Gill, G. J. P. 1983. "O-Phthaldialdehyde Precolumn Derivatization and Reversed-Phase High-Performance Liquid Chromatography of Polypeptide Hydrolysates and Physiological Fluids.” J. Chromotogr. 266: 471-82.

[13] Mitic, S. S., Kostic, D. A., Naskovic-Dokic, D. C., and Mitic, M. N. 2011. "Rapid and Reliable HPLC Method for the Determination of Vitamin C in Pharmaceutical Sample." Trop J. Pharm Res. 10 (1): 105-11.

[14] Glaser, A., and Biggs, C. 2010. An Introduction to Statistical Methods in GenStat.

[15] Abbas, M. F., Jasim, A. M., and Al-Zubaidy, B. H. 2012. "The Effect of Proline on Growth and Ionic Composition of Embryogenic Callus and Somatic Embryos of the Date Palm (Phoenix dactylifera L. CV. ASHKAR) under NACL Stress." Intl. J. Farm. \& Alli. Sci. 1 (3): 82-7.

[16] Said-Alahl, H. A. H., and Omer, E. A. 2011. "Medicinal and Aromatic Plants Production under Salt Stress. A Review." Herba Polonica 57 (1): 72-8.

[17] Maksimovic, I., and Ilin, Z. 2012. "Effects of Salinity on Vegetable Growth and Nutrients Uptake, Irrigation Systems and Practices in Challenging Environments." $J$. InTech. 169-90.

[18] Navarro, J. M., Flores, P., Garrido, C., and Martinez, V. 2006. "Changes in the Contents of Antioxidant Compounds in Pepper Fruits at Ripening Stages, as Affected by Salinity." Food Chemistry 96: 66-73.

[19] Campos, M. R. S., Gomez, K. R., Ordonez, Y. M., and Ancona, D. B. 2013. "Polyphenols, Ascorbic Acid and Carotenoids Contents and Antioxidant Properties of Habanero Pepper (Capsicum chinense) Fruit." Food and Nutrition Sciences 4: 47-54.

[20] Haghighi, Z., Karimi, N., Modarresi, M., and Mollayi, S. 2012. "Enhancement of Compatible Solute and Secondary Metabolites Production in Plantago Ovata Forsk. by Salinity Stress." J. Med. Plants Res. 6 (18): 3495-500.

[21] Misra, N., Gupta, A. K., and Dwivedi, U. N. 2006. "Changes in Free Amino Acids and Stress Protein Synthesis in Two Genotypes of Green Gram under Salt Stress.” J. Plant Sci 1: 56-66.

[22] Ranganayakulu, G. S., Veeranagamallaiah, G., and Sudhaka, C. 2013. "Effect of Salt Stress on Osmolyte Accumulation in Two Groundnut Cultivars (Arachis hypogaea L.) with Contrasting Salt Tolerance." Afr. J. Plant Sci. 7 (12): 586-92.

[23] Htwe, N. N., Maziah, M., Ling, H. C., Zaman, F. Q., and Zain, A. M. 2011. "Responses of Some Selected
Malaysian Rice Genotypes to Callus Induction under in vitro Salt Stress.” Afr. J. Biotechnol. 10 (3): 350-62.

[24] Sharma, S. S., and Dietz, K. J. 2006. "The Significance of Amino Acids and Amino Acid-Derived Molecules in Plant Responses and Adaptation to Heavy Metal Stress." J. Exp. Bot. 57 (7): 711-526.

[25] Shetty, K., and Wahlqvist, M. 2004. "A Model for the Role of the Proline-Linked Pentosephosphate Pathway in Phenolic Phytochemical Biosynthesis and Mechanism of Action for Human Health and Environmental Applications." Asia Pacific J. Clin. Nutr. 13 (1):1-24.

[26] Abbas, M. F., Jasim, A. M., and Al-Taha, H. A. 2013. "Effect of Exogenous Proline On Callus Growth Of Citrus Sinensis (L.), Osbeck Under Salt Stress.” Int. J. Natur. Sci. Res. 1-10.

[27] El Sayed, H., and El Sayed, A. 2013. "Exogenous Application of Ascorbic Acid for Improve Germination, Growth, Water Relations, Organic and Inorganic Components in Tomato (Lycopersicon esculentum Mill.) Plant Under Salt-Stress." New York Science Journal 6 (10): 123-39.

[28] Khafagy, M. A., Arafa, A. A., and El-Banna, M. F. 2009. "Glycinebetaine and Ascorbic Acid Can Alleviate the Harmful Effects of $\mathrm{NaCl}$ Salinity in Sweet Pepper." Aus. J. Cro. Sci. 3 (5): 257-67.

[29] Sevengor, S., Yasar, F., Kusvuran, S., and Ellialtioglu, S. 2011. "The Effect of Salt Stress on Growth, Chlorophyll Content, Lipid Peroxidation and Antioxidative Enzymes of Pumpkin Seedling." Afr. J. Agric. Res. 6 (21): 4920-4.

[30] Upadhyaya, C. P., Venkatesh, J., Gururani, M. A., Sharma, K., Ajappala, H., and Park, S. W. 2011. "Transgenic Potato Overproducing L-ascorbic Acid Resisted an Increase in Methylglyoxal under Salinity Stress via Maintaining Higher Reduced Glutathione Level and Glyoxalase Enzyme Activity." Biotechnol. Lett. 33 (11): 2297-307.

[31] Alami-Milani, M., and Aghaei-Gharachorlou, P. 2015. "Effect of Ascorbic Acid Application on Yield and Yield Components of Lentil (Lens culinaris Medik.) under Salinity Stress." Int. J. Biosci. 6 (1): 43-9.

[32] Kehie, M., Kumaria, S., and Tandon, P. 2012. "Osmotic Stress Induced-Capsaicin Production in Suspension Cultures of Capsicum chinense Jacq.cv. Naga King Chili." Acta Physiol Plant 34 (2).

[33] Ali, T. B., Khalil, S. E., and Khalil, A. M. 2011. "Magnetic Treatments of Capsicum Annuum L. Grown under Saline Irrigation Conditions." J. Appl. Sci. Res. 7 (11): 1558-68. 